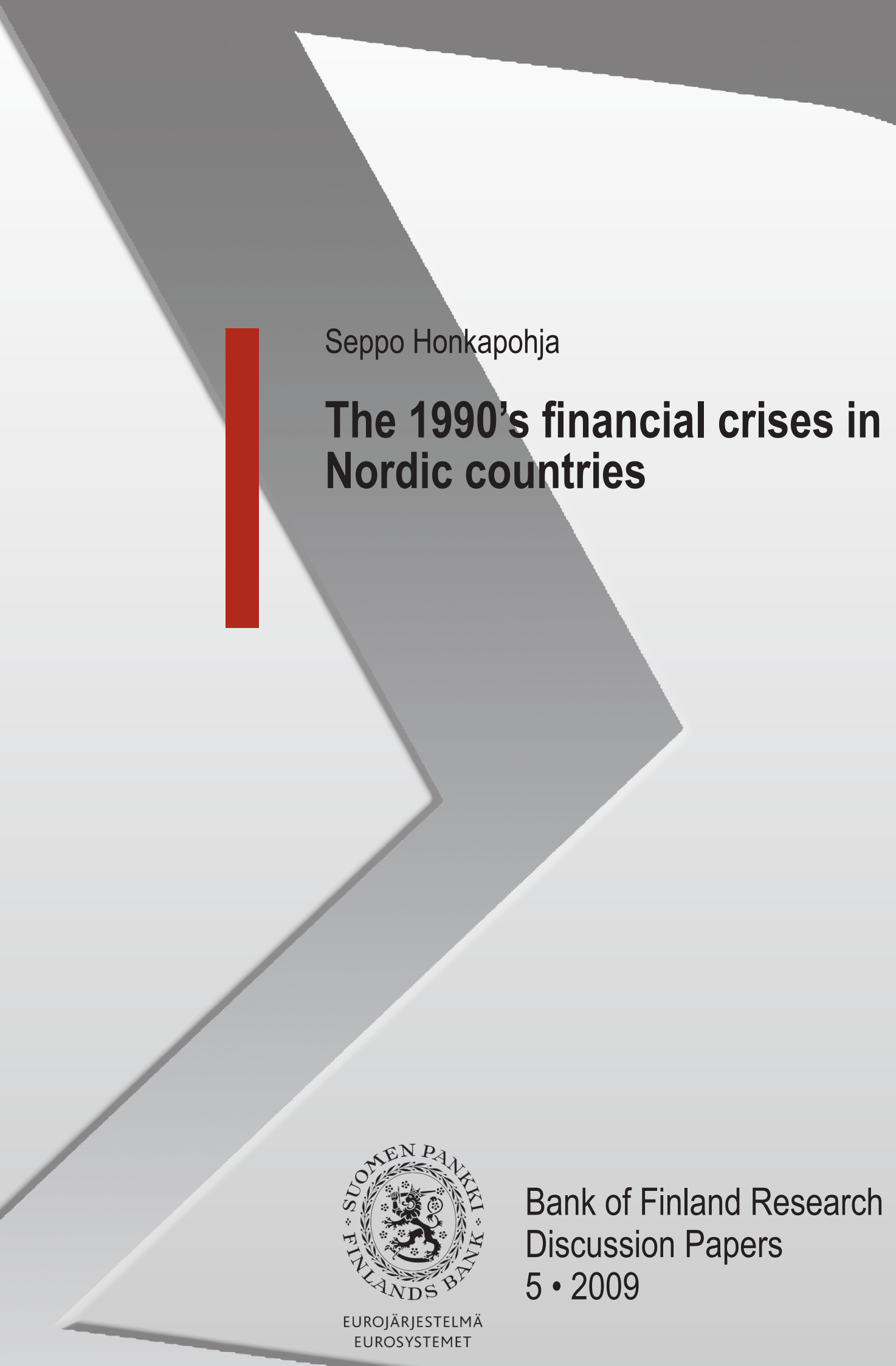


Suomen Pankki

Bank of Finland

PO Box 160

FI-00101 HELSINKI

Finland

I +35810 8311

http://www.bof.fi 


\author{
Bank of Finland Research \\ Discussion Papers \\ $5 \cdot 2009$
}

Seppo Honkapohja*

\title{
The 1990's financial crises in Nordic countries
}

The views expressed in this paper are those of the author and do not necessarily reflect the views of the Bank of Finland.

* E-mail: seppo.honkapohja@bof.fi

Speech in the Global Interdependence Center, Philadelphia USA, September 30th, 2008. I am grateful to Antti Kuusterä, Jorma Hilpinen, Jarmo Pesola, and Juha Tarkka for comments and to Hanna Putkuri for assistance. 
http://www.bof.fi

ISBN 978-952-462-490-9

ISSN 0785-3572

(print)

ISBN 978-952-462-491-6

ISSN 1456-6184 (online)

Helsinki 2009 


\title{
The 1990's financial crises in Nordic countries
}

\author{
Bank of Finland Research \\ Discussion Papers 5/2009
}

Seppo Honkapohja

Monetary Policy and Research Department

\begin{abstract}
The current financial crisis, which has lasted almost one and a half years, is the 19th such crisis in the post-war period in advanced economies. Recent literature classifies the Nordic crises in Norway, Sweden and Finland in late 1980's and early 1990's among the Big Five crises that have happened before the current crisis, which is now of a global nature. This paper outlines the developments of the Nordic crises, reasons behind them and crisis management by the authorities. Relatively more emphasis is placed on the Finnish crisis, as it was the deepest one. The paper concludes by considering the lessons that can be drawn from the Nordic crises.
\end{abstract}

Keywords: financial deregulation, bank lending, overheating, financial crisis

JEL classification numbers: G01, G21, E44 


\title{
1990-luvun rahoituskriisit Pohjoismaissa
}

\section{Suomen Pankin keskustelualoitteita 5/2009}

\author{
Seppo Honkapohja \\ Rahapolitiikka- ja tutkimusosasto
}

\section{Tiivistelmä}

Meneillään oleva, kohta puolitoista vuotta kestänyt rahoituskriisi on järjestyksessään 19. toisen maailman sodan jälkeinen kriisi kehittyneissä talouksissa. Viimeaikainen tutkimus on erottanut meneillään olevaa kriisiä edeltävistä 18 rahoituskriisistä viisi suurta, joihin Norjan, Ruotsin ja Suomen 1980-luvun lopun ja 1990luvun alun kriisit kuuluvat. Tässä paperissa kuvataan ensin kriisien kehittyminen näissä pohjoismaissa, jonka jälkeen tarkastellaan kriiseihin johtaneita syitä ja viranomaisten toimia kriisien hallitsemiseksi. Suomen rahoituskriisi saa tarkasteluissa suhteellisesti ottaen enemmän painoa, koska se oli näistä kolmesta kaikkein syvin. Tarkastelujen lopuksi pohditaan mitä pohjoismaiden rahoituskriiseistä voitaisiin oppia.

Avainsanat: rahoitusmarkkinoiden sääntelyn purkaminen, pankkien luotonanto, ylikuumeneminen, rahoituskriisi

JEL-luokittelu: G01, G21, E44 


\section{Contents}

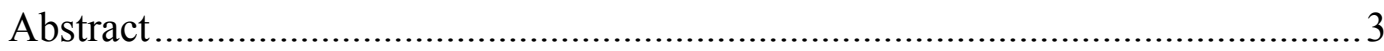

Tiivistelmä (abstract in Finnish) ............................................................... 4

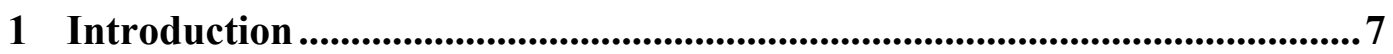

2 Overview of the volatile economies................................................................8

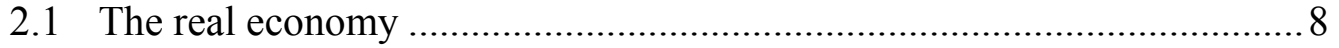

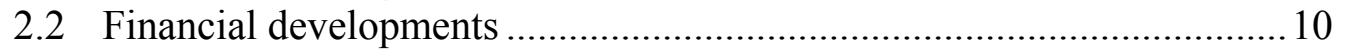

3 Reasons behind the crises .......................................................................14

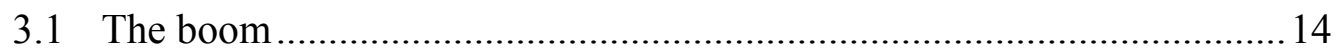

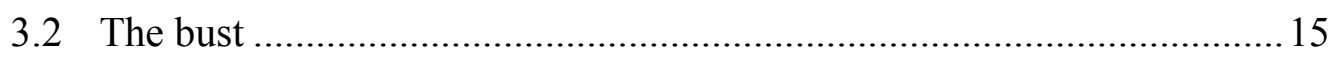

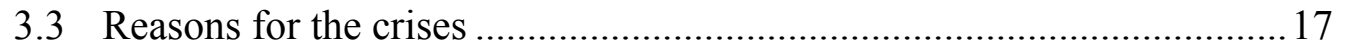

4 Management of the crises .......................................................................20

4.1 Management of the Finnish banking crisis..........................................20

4.2 Management of the Swedish banking crisis .........................................22

4.3 Management of the Norwegian banking crisis ....................................22

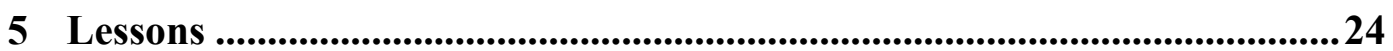

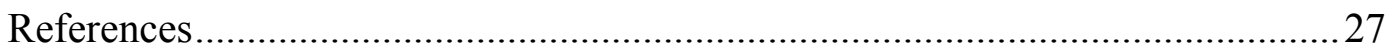




\section{Introduction}

The current financial turmoil has now lasted well over a year. In the postwar period, the current crisis is the 19th in advanced economies and the first one in the 21 st century. In a recent paper Carmen Reinhard and Kenneth Rogoff (2008) divide the 18 crises before the current US subprime crisis into 'Big Five' and smaller crises. The Big Five include the crises in Norway, Finland and Sweden that occurred mostly in early 1990's. The Norwegian crisis started already in late 1980's but continued into 1990's.

Nearly all major banks in the Nordic countries got into difficulties and made huge losses, with average loss provisions (expressed as percentage of lending) in the period 1982-1993 ranging from 2.1 (in Denmark) to 1.5 per cent (in Finland and Norway) of bank lending. In the sub-period 1990-1993 loss provisions were 2.9 per cent for Denmark, 3.4 per cent for Finland, 2.7 per cent for Norway, and 4.8 per cent in Sweden. ${ }^{1}$ All of the Nordic countries had to provide public support to their banking systems. In Denmark this support was small whereas in Norway, Sweden and Finland public support was quite significant with increasing importance in the indicated order of countries. The financial crises in Finland, Norway and Sweden became systemic, whereas Denmark avoided a systemic crisis. Thus, I will not cover the Danish case in any detail.

Even though each financial crisis has its own particular features, experiences and lessons from earlier crises can provide useful insights for understanding later crises. My goal today is to outline the developments of the Nordic crises, reasons behind them, and the crisis management by the authorities. I will put some emphasis on the Finnish case, because it was the deepest crisis of the three and because it is my home country.

My speech is organized as follows. First, I will describe the main features and stages of the crises. Second, I will analyze the reasons behind them. The crises differed, but there were also common features. Third, I will discuss how the public authorities in the three countries managed the crises. Finally, I will consider lessons from the Nordic crises.

Before I start, I must say a few words about my perspective on the subject. In the early 1990s I was a Professor in the University of Helsinki and had no official connection to the Finnish authorities handling the crisis. I was, to an extent, a critic of the policies, especially at the early stage of the Finnish crisis. However, this period influenced me greatly; it was the starting point of my occasional public appearances to discuss economic policies. I must also note that my role in economic policy discussions recently changed when I became a policymaker as Member of the Board of the Bank of Finland in the beginning of 2008.

\footnotetext{
${ }^{1}$ These figures are from Møller and Nielsen (1995).
} 


\section{Overview of the volatile economies ${ }^{2}$}

I now describe the main macroeconomic and financial developments in Finland, Norway and Sweden in Figures 2.1-2.9, starting from mid 1980's. The figures show, respectively, annual GDP change (in \%), current accounts in per cent of GDP, unemployment rates (in \%), real residential property prices (indices $1980=100$ ), real share prices (indices $1980=100$ ), annual growth in bank lending (in \%), loans to GDP ratio in per cent, and loan loss provisions by bank groups in each country.

\subsection{The real economy}

Starting with economic growth, shown in Figure 2.1, it is seen that the Finnish experience was quite dramatic. Finland experienced relatively fast growth in the second half of 1980s, and the economy became overheated at the end of the decade. The country then plunged into a deep recession in the beginning of 1990s, with negative growth for about three years. The total cumulative fall in GDP was well over ten per cent from peak to trough. After that Finland experienced a fast recovery and growth has remained strong to the present day, with some normal cyclical fluctuations.

Figure 2.1

Real GDP growth

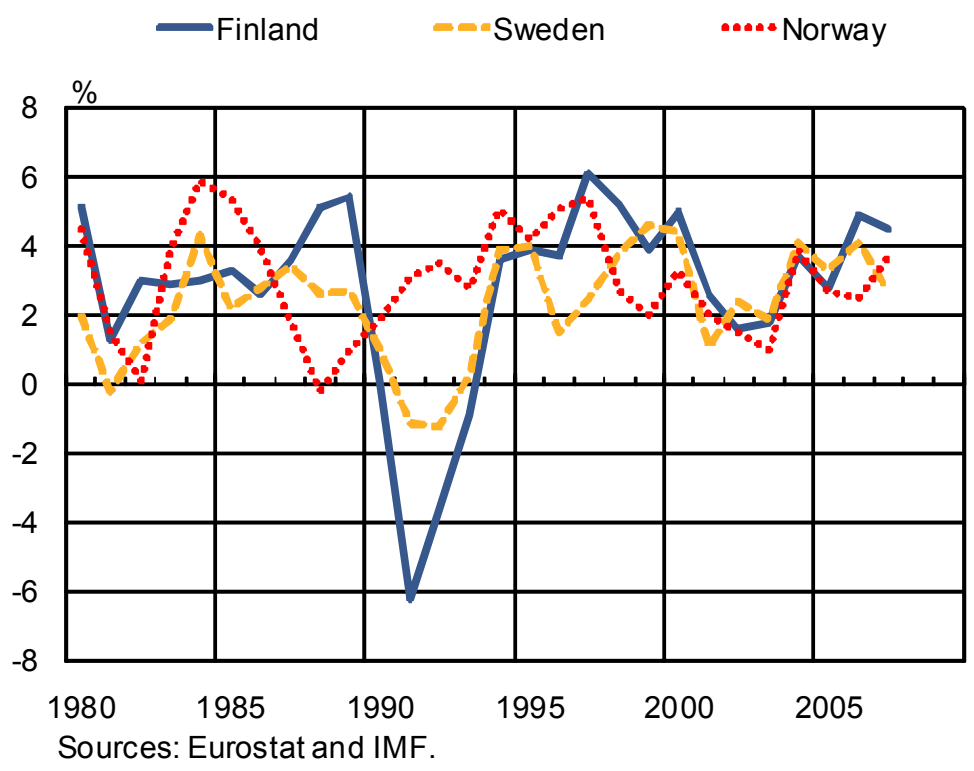

\footnotetext{
${ }^{2}$ See Honkapohja and Koskela (1999), Englund (1999) and Steigum (2004) for overviews of the three countries.
} 
Figure 2.2

\section{Current account}

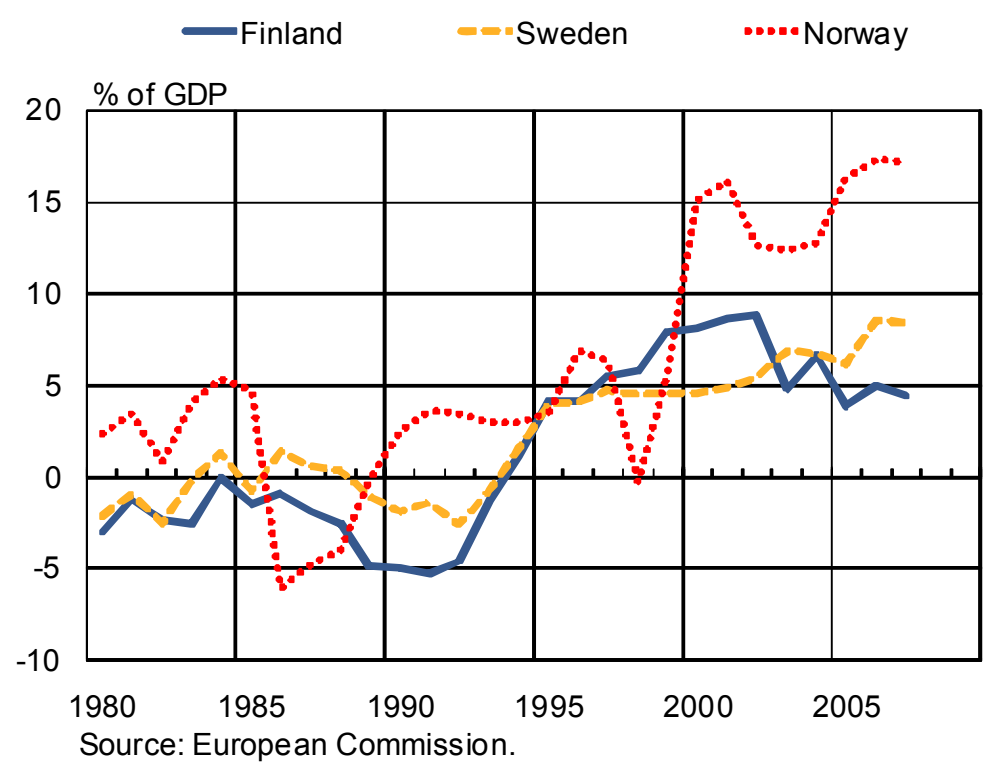

Figure 2.3

\section{Unemployment rate}

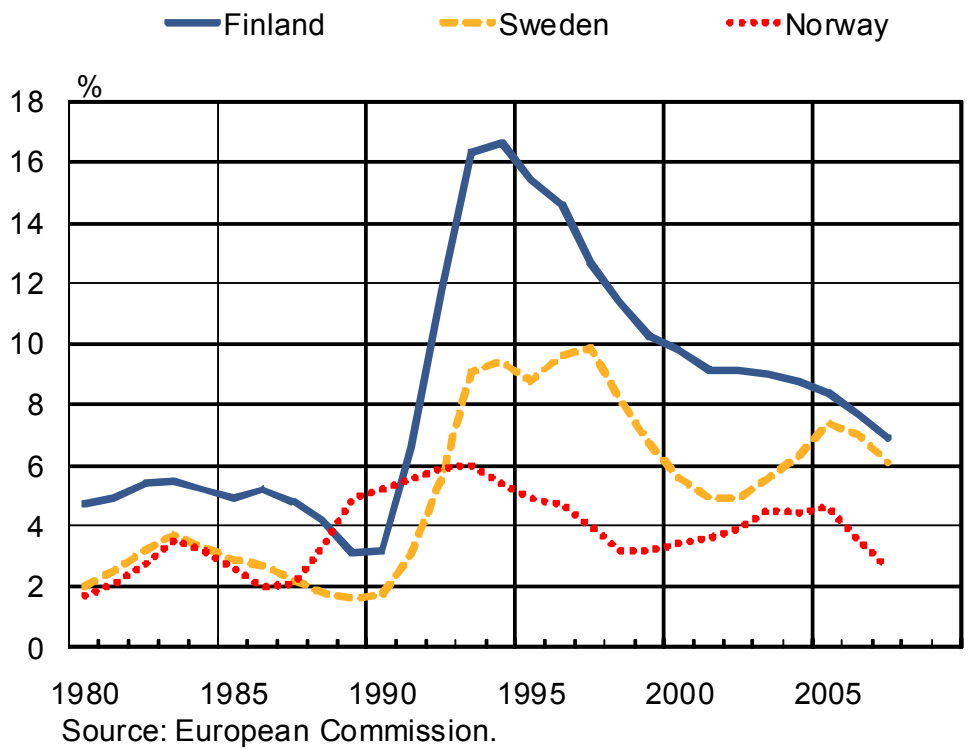

The Swedish experience is qualitatively similar but less extreme. Sweden had relatively rapid growth performance in the 2 nd half of 1980 s, though it grew more sluggishly than Finland. It also plunged into a recession, with negative growth in the beginning of 1990s, but the recession was not as deep as in Finland. Recovery was also fast and after the crisis Swedish growth performance has been good and, indeed, somewhat better than before the recession. 
The Norwegian case is different from the other two. Norway experienced difficulties already in the second half of 1980s, with growth rate around zero in 1987. This was due to a major decline in oil prices in 1986, which in view of the big role of oil led to a slowdown of the economy. The slowdown lasted well into the beginning of 1990s. Overall, the Norwegian crisis was less severe than the Swedish case (and a fortiori the Finnish one) as it did not experience any significant period of negative growth. The sluggish period in Norway lasted longer than in Finland and Sweden, but the country has recovered well.

Looking at current accounts in Figure 2.2, it is seen that Finland and, to somewhat lesser extent, Sweden faced major external deficits in the second half of 1980s. These deficits turned into surpluses after the crises and current accounts have remained in surplus ever since. The Norwegian experience was different: the decline in oil prices resulted in current accounts deficits from 1986 to 1988 but the external balance has been positive otherwise. It can be noted that all three countries experienced speculative attacks during the crisis and these attacks were quite strong for Finland and Sweden. All three countries eventually abandoned the fixed exchange rate regime.

Development of unemployment in the three countries, shown in Figure 2.3, is broadly a mirror image of GDP developments. All three countries initially had low unemployment, which started to rise a part of the financial crises. Norway experienced the rise earlier than Finland and Sweden. As the Finnish crisis was the deepest, the unemployment rate increased by far the most during the crisis. In all three countries unemployment has gradually fallen once the crisis receded. ${ }^{3}$

\subsection{Financial developments}

Figure 2.4 shows the developments in residential property prices. The developments are qualitatively similar in the three countries, with movements in Norway taking place earlier. Property prices rose rapidly during the booms and declined sharply during the financial crises. Finland had the most extreme movements. Property price movements were also strong in Norway and it can be noted that the decline from 1986 lasted quite long, ending only in 1993. The Swedish case is less extreme than the Norwegian one and the Swedish prices also turned around relatively slowly. In contrast, the up- and downswings in Finnish property prices were faster than in the other two countries.

\footnotetext{
${ }^{3}$ It should be noted that unemployment in Finland is systematically higher than in Norway or Sweden.
} 
Figure 4.4

Figure 4.5
Real house prices
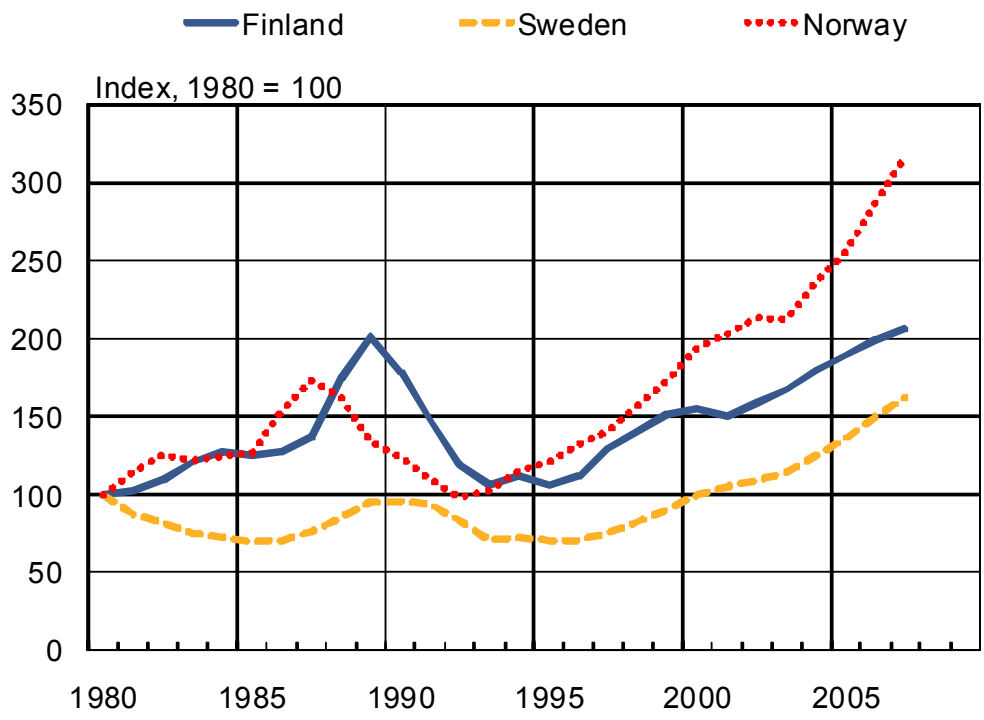

Nominal house prices deflated using the consumer price index.

Sources: Statistics Finland, Statistics Sweden, Norges Bank and Bank of Finland.

\section{Real share prices}
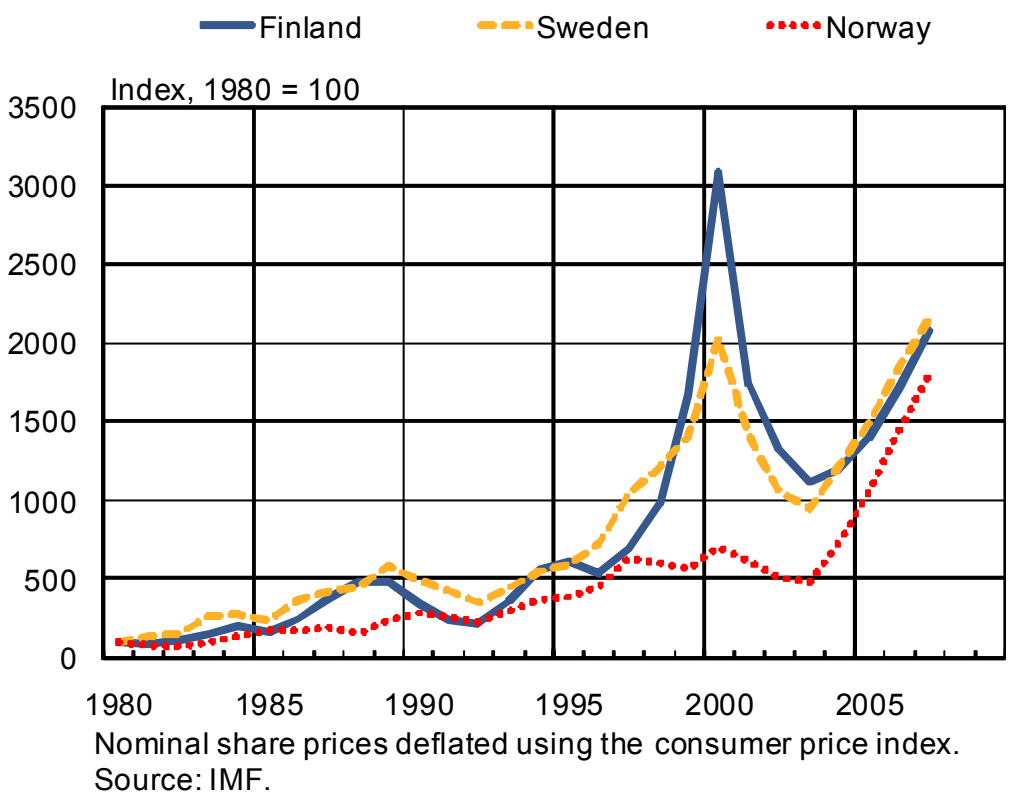


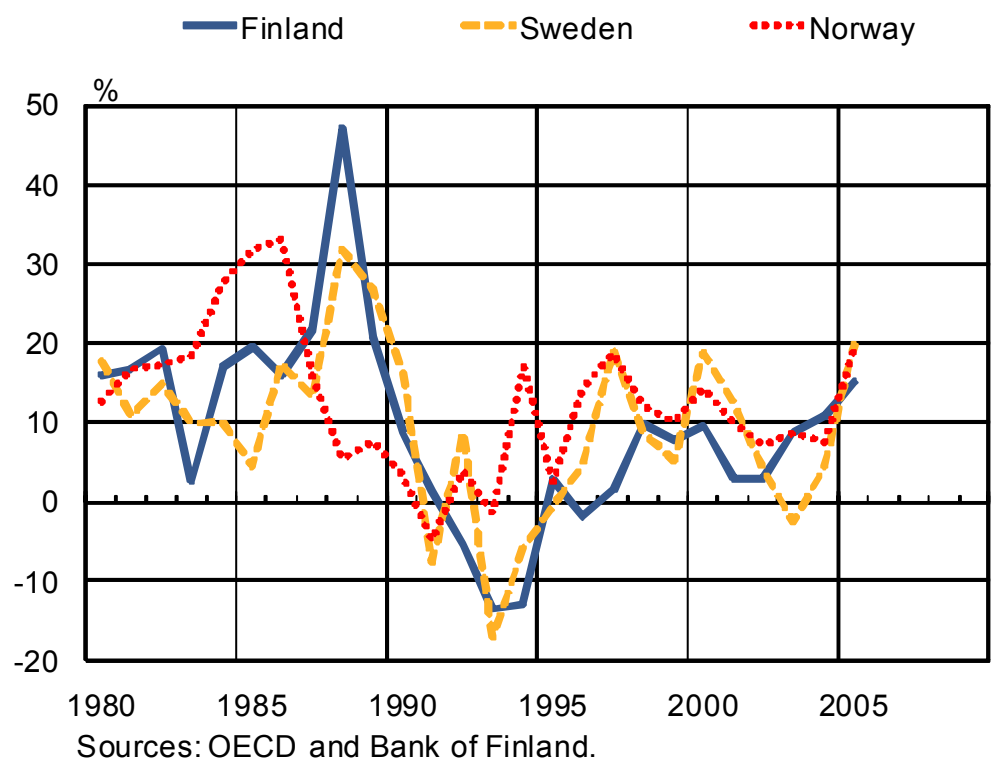

Dynamics of share prices, shown in Figure 2.5, in Finland and Sweden tell roughly the same story as residential property prices. Share prices rose rapidly from mid 1980s to the end of the decade, after which they experienced a major decline for about three years. In contrast, Norwegian share prices moved much less during the 1980s and early 1990s. ${ }^{4}$

Next, I consider bank lending. Figure 6 shows the annual growth rates in bank lending for the three countries. It is seen that each country experienced fast growth in lending during the boom years in the 1980's. The Norwegian boom is seen to happen earlier than those of Finland and Sweden. The boom and bust in lending were most extreme in Finland. Quite remarkably, both Finland and Sweden had negative lending growth for several years. The loans to GDP ratio rose rapidly during boom years and declined by almost the same amount in the recessions in Finland and Sweden. In Norway, the decline was much smaller.

To conclude the overview, we look at realized loan loss provisions of banks in the three countries in Figures 2.7-2.9. The figures show loss provisions as percentage of balance sheet for the major parts of the banking system. It is seen that in each country these loss provisions rose rapidly in the beginning of the crisis. In Finland the crisis was deepest for savings bank group, whereas in Norway commercial banks had the highest loss provisions. In Sweden different banking groups had similar loss provision developments. The heavy losses led to

\footnotetext{
${ }^{4}$ The figure shows huge increases and subsequent in share prices in Finland and Sweden (but not in Norway) around the turn of the century. These developments are the result of the IT revolution as Nokia dominates the Finnish stock market and Eriksson is similarly a very large player in the Swedish stock market.
} 
significant restructuring of the banking systems and I will come back to these later.

Figure 2.7

\section{Loan loss provisions in Finland}

Commercial banks $\cdots$ C..Savings banks - - Cooperative banks

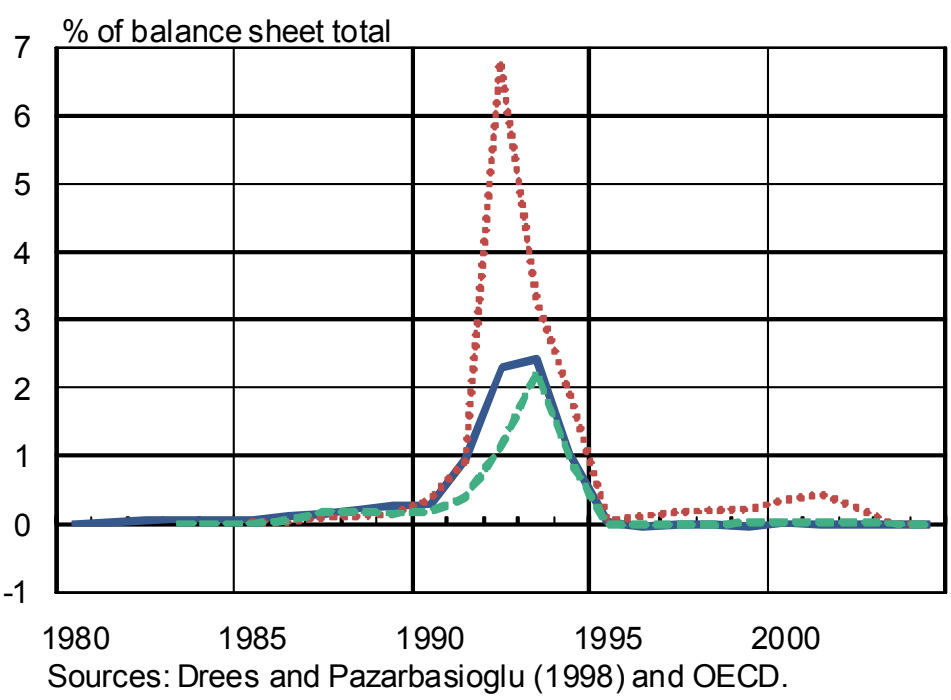

Figure 2.8

\section{Loan loss provisions in Sweden}

Commercial banks $\cdots$ Savings banks $=-{ }^{-}$Cooperative banks

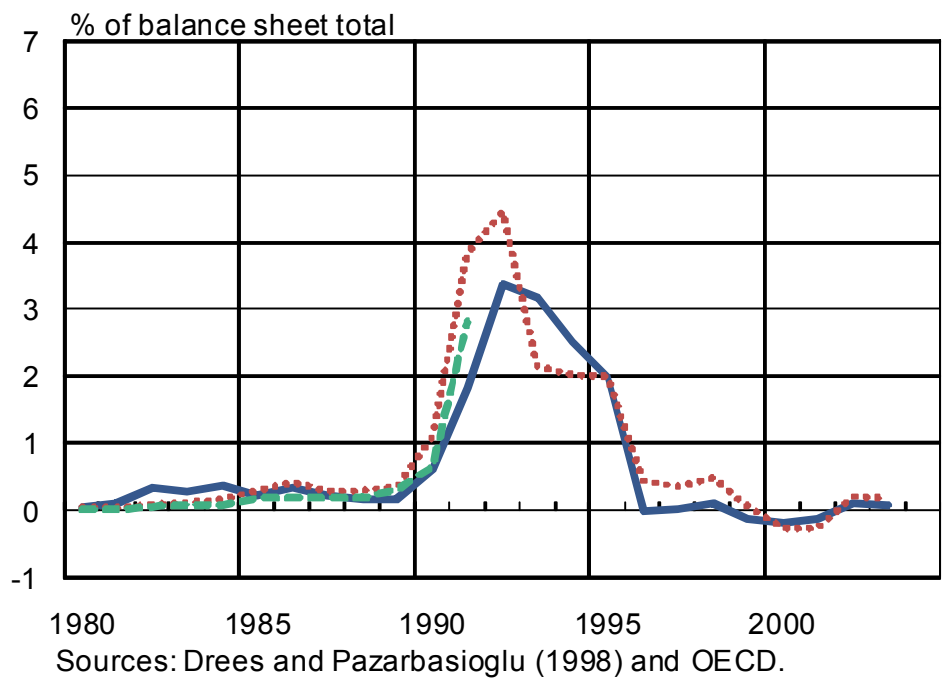


Figure 2.9

\section{Loan loss provisions in Norway}

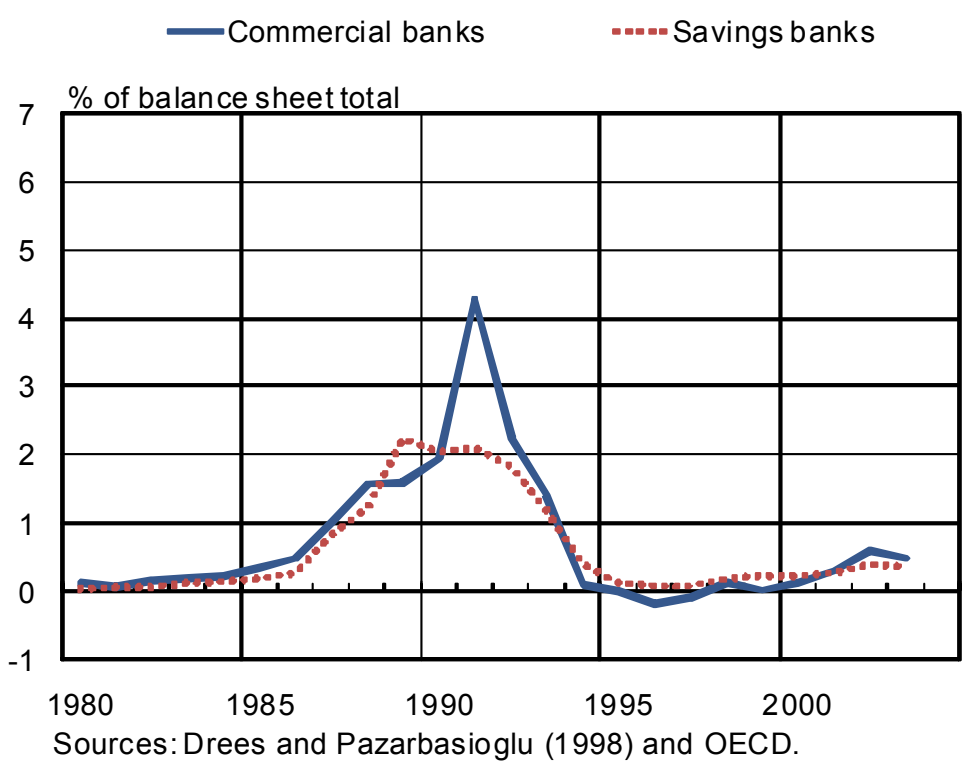

The macroeconomic and financial developments just described suggest that the nexus of financial deregulation, macroeconomic policies, and the external economic environment has major consequences for the occurrence of financial crises. Below I examine these connections further.

\section{Reasons behind the crises}

Let me next consider the main factors behind the crises. I will discuss the Finnish case in some detail and then just comment on the Norwegian and Swedish cases.

\subsection{The boom}

The Finnish economy performed relatively smoothly in the 1st half of 1980s. Despite gradual disinflation, the Finnish inflation rate remained higher than the rates of its main competitors and there was a deterioration of its international competitiveness. The smooth ride began to get bumpy around 1986-1987. Economic growth accelerated significantly and the economy gradually entered a period of overheating. Several factors were behind this change.

First, financial market deregulation led to an explosion of domestic bank credit as we saw in the earlier figure. As will be discussed further below, the process of deregulation was not carried out in the most logical way. Following the financial deregulation, banks had to adjust a new regime of price-competition 
instead of competition with service provision in the regulated era. The new possibilities for competition between banks led to increased risk-taking as a result of moral hazard and myopic behavior.

Second, freeing of international capital movements led to a huge increase in capital inflows, a significant fraction of which was denominated in foreign currencies and not hedged. Restrictive monetary policy accentuated the capital inflows as a result of the interest rate differential between domestic and foreign interest rates and partly because investors perceived a small likelihood of loss from exchange rate movements.

Third, a sharp increase in the terms of trade resulting from a falling energy prices and a rise in world market prices of forest products contributed to the overheating of the economy that was already fuelled by the financial deregulation. The business cycle was in an upswing in many countries, partly as a result of the loose monetary policy after the 1987 stock market crisis. This added to the bad luck of overheating in Finland and Sweden. Domestic economic policies were not sufficiently restrictive to counteract the boom.

In the process of overheating, the rate of inflation rose from about 2-3 per cent in 1986 to about 7 per cent in 1989-1990. The rate of unemployment declined from the about 4 per cent in the first half of the decade to $2.5-3$ per cent at the end of 1989. The external balance for Finland worsened and serious current account problems emerged. It may be noted that Sweden experienced less overheating in the second half of the decade. For 1985-1990, the average current account deficit-to-GDP ratio was 2.9 per cent for Finland, while the corresponding figure for Sweden was only 1.1 per cent.

The overall developments in the upswing before the Norwegian and Swedish crises in were similar to those for Finland. Financial market deregulation and positive international business-cycle developments were the main factors behind the domestic booms and rapidly rising real asset and share prices. However, for Norway the major fall in oil prices in 1986 was a major negative shock that prevented a longer-lasting boom and a correspondingly bigger bust.

\subsection{The bust}

The end of the boom in Finland came in 1990, and a rapid descent ensued. Economic activity, as measured by the growth rate of real GDP, declined swiftly from positive growth of $5.4 \%$ in 1989 to negative growth of $-6.5 \%$ in 1991 . Domestic private investment and private consumption fell sharply, while net exports of goods and services started to pick up toward the end of 1991. The decline continued, though at a slower pace through 1992 and most of 1993. A turnaround took place in the fall of 1993. Price inflation slowed down 
significantly and nearly vanished. The Finnish markka was devalued in November 1991 and then floated in September 1992. After these developments, the current account deficit gradually disappeared and shifted to surplus.

Both international and domestic factors contributed to the onset of Finnish crisis. First, Finnish exports to market economies declined as a result of slow international growth, loss in the price competitiveness of Finnish industry, and a decline in the terms of trade. With the collapse of the former Soviet Union, Finnish exports and imports to Russia quickly dropped by 70 per cent in March 1991. This significantly contributed to the decline in Finnish GDP in the crisis years.

Second, after German unification, interest rates rose in Europe and also in Finland, as a result of more expansive fiscal policy combined with tighter monetary policy in Germany.

Third, monetary conditions became very restrictive due to an increase in real interest rates and appreciation of the Finnish markka. Real interest rates rose dramatically from the start of 1990 until the end of 1992 as a result of the defense of the Finnish markka against speculative attacks with high nominal interest rates and because of the fall in the inflation rate at the onset of recession. Figure 3.1 shows the interest rate differential between Finland and Germany and the Finnish real interest rate. Figure 3.2 shows the exchange rate for the Finnish markka.

Figure 3.1

\section{Real interest rate in Finland and interest rate differential to Germany (3-month rates)}

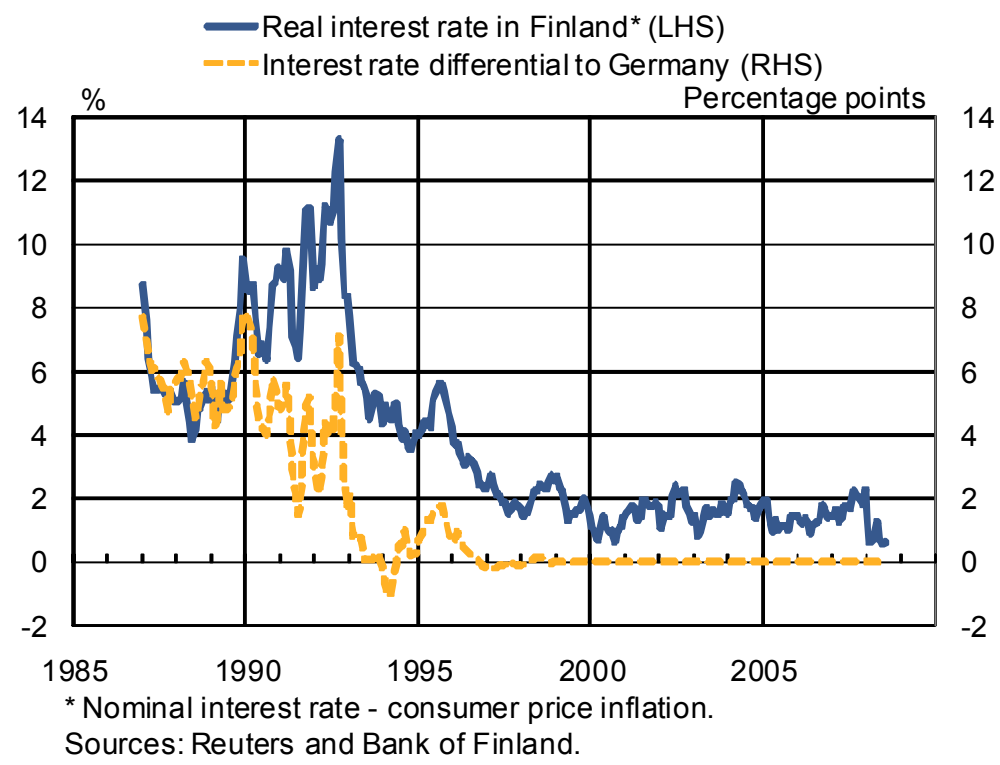




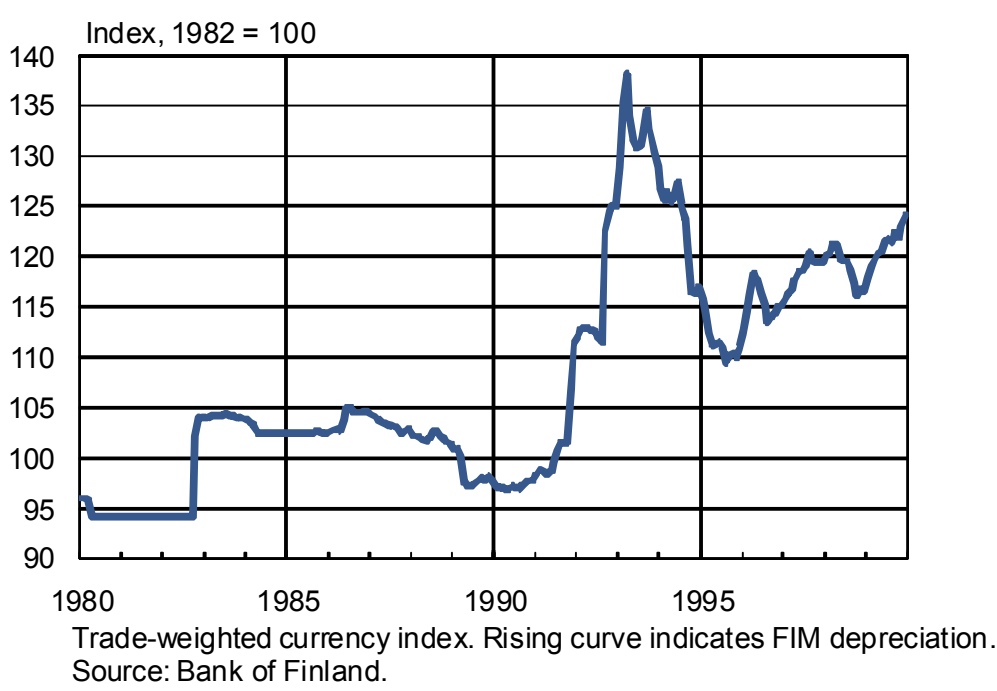

In Sweden the reasons for the onset of the crisis were similar to those for Finland, ie Sweden also experienced the high German interest rates and speculative attacks against the Swedish krona. ${ }^{5}$ There was, however, one major difference to Finland. Sweden had little trade with the Soviet Union, so that the break-down of Soviet Union had no economic impact on Sweden. Moreover, lack of trade with the Soviet Union meant that Swedish industry had been forced to modernize already before the 1908s. In contrast, large trade with Soviet Union had led to lack of competitiveness of parts of Finnish industry in western markets. These factors meant that the Swedish crisis was not as deep as the Finnish one. Both economies started to recover in 1993-1994.

For Norway, I already mentioned that the turnaround of the boom came already in 1986 with the decline of oil prices. The Norwegian krona was devalued by 6 per cent in response to this decline and restrictive policies were introduced. Inflation gradually declined from 1987 and by 1990 the rate of inflation went below the average rate of its trading partners. The crisis in Norway lasted a fairly long time and the turn round of the business cycle occurred in 1993.

\subsection{Reasons for the crises}

The emergence of major banking crises was a notable feature of the bust process in all three Nordic crises. A deep financial crisis also emerged in Norway, even though the fluctuations in the real economy were much smaller than those in

\footnotetext{
${ }^{5}$ You may recall that Swedish interest rates briefly reached even 500 per cent during the defense of the currency.
} 
Finland and Sweden. The latter countries had severe declines in GDP, which in turn contributed to the financial crises.

For concreteness, I again look at the Finnish case. The roots of the boom-bust cycle and the financial crisis can be traced back to the deregulation of the financial system in the 1980's. The process of financial deregulation began in the early 1980's, but the greater part of it was carried out in the second half of the decade. Liberalization of domestic financial markets and of international capital flows was implemented at a time when interest rates in Finland were much higher than abroad. This caused a massive capital inflow that led to uncontrolled credit expansion. This effect was also strong in Sweden and it operated, to a lesser extent, in Norway; see Sandal (2004).

The deregulation process was problematic in several respects. First, it's timing in the second half of the 1980's coincided with the upswings of business cycles in Western market economies. As was already noted, the big boom led to soaring indebtedness in the private sector, higher relative unit labor costs, and a current account deficit. Later on, it led to speculative attacks on the Finnish markka.

Second, the prevailing banking law from 1969 was outdated and bank supervision focused on solely legalistic monitoring of banks. The rules and practices in prudential regulation and bank supervision were left unchanged in the deregulation process. These were tightened only later in 1991, when the depression had already begun.

Third, the tax system favored debt financing of business and housing investment and it was reformed only later. Some reforms were attempted during the boom years but there was little political support for the reform proposals.

Fourth, in the context of deregulation, lending rates were liberated before deposit rates, which also helped to ease the banks' position. Finally, monetary policy under a fixed exchange rate with a narrow band tried to maintain some tightness in the wake of the boom. This provided further impetus to the large (in foreign currency terms) inflow of foreign capital. The capital inflows to private sector were mediated largely by Finnish banks and led to foreign-currencydenominated borrowing also by firms operating in the non-tradable sector.

The financial crisis had also an international dimension for Finland and Sweden. (Norway suffered less in this dimension.) For both countries problems of international indebtedness and illiquidity emerged and, as I argued above, these features result from an earlier real appreciation and lending boom after financial deregulation. Next, I briefly compare Finland's and Sweden's international indebtedness to those of Mexico, Chile and East Asian countries.

A country may be able to withstand a relatively high level of international indebtedness, provided its economic growth remains solid, the debt is largely long-term, and the confidence of international investors remains intact. Nevertheless, a high international debt position means increasing risks, should a 
country run into economic difficulties. Table 3.1 shows the external debt-to-GDP ratio for Finland and Sweden for the period 1982-2001. For comparison, the table also shows the data for Chile (1984-2001), for Mexico (1984-1993), for Korea (1990-2001), and for Thailand (1995-2001).

Table $3.1 \quad$ International Indebtedness ${ }^{6}$

International Indebtedness: Net foreign debt, \% of GDP

\begin{tabular}{|c|c|c|c|c|c|c|}
\hline & Finland & Sweden & Mexico & Chile & Korea & Thailand \\
\hline 1982 & 17 & 19 & & & & \\
\hline 1983 & 20 & 22 & & & & \\
\hline 1984 & 19 & 20 & 48 & 73 & & \\
\hline 1985 & 19 & 21 & 46 & 88 & & \\
\hline 1986 & 17 & 19 & 58 & 85 & & \\
\hline 1987 & 20 & 17 & 53 & 74 & & \\
\hline 1988 & 19 & 19 & 41 & 50 & & \\
\hline 1989 & 23 & 21 & 31 & 33 & & \\
\hline 1990 & 45 & 26 & 30 & 17 & -32 & .. \\
\hline 1991 & 50 & 28 & 26 & 17 & 10 & .. \\
\hline 1992 & 53 & 23 & 22 & 14 & 11 & .. \\
\hline 1993 & 54 & 41 & 20 & 16 & 20 & .. \\
\hline 1994 & 63 & 45 & & .. & 23 & .. \\
\hline 1995 & 56 & 39 & & .. & .. & 32 \\
\hline 1996 & 54 & 39 & & .. & .. & 35 \\
\hline 1997 & 46 & 39 & & 33,7 & .. & 49 \\
\hline 1998 & 87 & 38 & & 37,7 & .. & 57 \\
\hline 1999 & 180 & 31 & & 35,4 & .. & 38 \\
\hline 2000 & 140 & 25 & & 37,1 & .. & 48 \\
\hline 2001 & 74 & . & & 41,7 & 152 & 43 \\
\hline
\end{tabular}

Sources: IMF

Crisis: 1992-93 EMS crisis, 1994-95 Mexican meltdown and 'Tequila Hangover', 1997-98 'Asian Flu'. Source: FRB of San Francisco, Economic Letter, August 1998 Countries affected by crisis. Source: World Economic Outlook, 1998

The build-up of international debt for Finland is seen to be quite significant because the Finnish current account deficits were large before the crisis. In contrast, Sweden shows a similar but more gradual build-up of foreign debt. This suggests that the external situation for Finland, and to an extent for Sweden, was relatively risky, so that the pressures mounted rapidly once the general outlook became gloomy in 1990-1991.

In comparison, international indebtedness for Mexico was very high in the 1980s and even higher for Chile in the mid-1980s. Thailand experienced a fairly rapid increase in its foreign indebtedness in 1997-1998. These indebtedness problems were a central element in financial crises in these countries.

Table 3.1 suggests that the financial crisis in Finland and Sweden had features similar to those in Chile, Mexico, Indonesia, Korea, Malaysia and Thailand.

\footnotetext{
${ }^{6}$ The table is from Honkapohja et al (2008). Note that the figures include foreign ownership of equity capital, which in the Finnish case distorts the figures at the end of 1990s because of the high share prices and large foreign ownership of the Nokia corporation.
} 
Finland and Sweden went through a 'twin crisis', ie a combined currency and banking crisis.

\section{$4 \quad$ Management of the crises}

The Nordic financial crises required major policy interventions by the governments and parliaments. I next describe the main features of crisis management in the three countries, focusing first on the deepest crisis, ie Finland. After that I discuss crisis management in Norway and Sweden. All three countries are considered in some detail as each case can give specific lessons.

Before analyzing these cases, I want to comment on the reasons why Denmark avoided a systemic banking crisis even though the loan losses of Danish banks were significant and a few Danish banks had to be rescued by the public sector. $^{7}$ One reason for the better Danish performance was good luck with the timing of reforms. Denmark started to deregulate the financial system earlier than the other three Nordic countries, and this happened before the boom years in the second half of 1980s. For example, interest deductibility provisions were reduced in a tax reform, which reduced attractiveness of debt finance. Prudential supervision and disclosure rules and capital adequacy requirements for Danish banks were made stricter than for other Nordic banks. The better condition of Danish banks explains why in difficult times in the beginning of 1990s, most Danish banks were able to raise new private equity in conjunction with costcutting and restructuring operations and little public intervention was needed.

\subsection{Management of the Finnish banking crisis ${ }^{8}$}

Policy actions to overcome the Finnish banking crisis began in September 1991 when the Bank of Finland had to take control of Skopbank, the 'central bank' of the Savings bank system as other banks refused accept certificates by Skopbank. This was an unusual but necessary step as no other public institutional arrangement existed for rescuing a bank in major difficulties. ${ }^{9}$

\footnotetext{
${ }^{7}$ See Koskenkylä (2000) and Moeller and Nielsen (1995) for more details. See Edey and Hviding (1995) for comparisons of financial reform in OECD countries.

${ }^{8}$ Largely based on Honkapohja et al (2008) and Honkapohja and Koskela (1999). See also Nyberg and Vihriälä (1994), Vihriälä (1997), and Koskenkylä (2000) for discussions of the Finnish crisis.

${ }^{9}$ Bank of Finland sold Skopbank in June 1992 to the newly established Government Guarantee Fund. The operation was quite costly to the Bank of Finland, with net cost of around 11 billion FIM plus foregone interest income (around 2,65 billion USD using the exchange rate of 4.15 prevailing at the end of 1991.)
} 
Further policy measures were initiated in early 1992. The government injected public funds, in the form of preferred capital certificates, into the banking system and set up a Government Guarantee Fund (GGF) to manage the banking crisis. Tight conditions were imposed on the public support to the banks as the capital certificates could be converted into voting stock if certain conditions about repayment and bank solvency were not fulfilled. Moreover, the interest rate on the certificates was set slightly above the market rate. Correspondingly, further GGF actions included strict requirements on the banks including transparency of support, monitoring of banks receiving support, terms to support efficiency and structural adjustment of the banking system, and (in varying degrees) financial responsibility of owners of banks receiving support.

As the crisis continued, the government (in August 1992) and the Parliament (in the beginning of 1993) made public promises that the obligations of the Finnish banking system would be guaranteed under all circumstances. In early 1993 the GGF was strengthened and it was given additional capital. Public support of the banking industry continued through 1994. A modest improvement in the banking sector took place in 1993, and further improvements came in 1994 and 1995. Loss making by banks stopped only in 1996, and since 1997 the banks have made significant positive profits. In the end, most of the public support for banks went to the savings banks.

Improved efficiency of Finnish banks was achieved through reduction of the number of branches and staff. For example, the number of staff was approximately halved in eight years from 1990 to 1998. Major restructuring of the banking sector took place during the crisis. Most of the 250 Savings banks were combined into the Savings Bank of Finland (SBF) in June 1992. The new bank was, however, not viable and subsequently SBF was split and the pieces were merged with the commercial and cooperative banks as well as the governmentowned Post-Office Bank. The non-performing assets of SBF were transferred to an asset management company, Arsenal, which was owned by GGF. A small commercial bank, STS-Bank, was merged with a big commercial bank (KOP). In $1995 \mathrm{KOP}$, one of the two big commercial banks was in turn merged with the other big commercial bank (SYP) to form Merita Bank.

After the crisis, structural changes continued with the merger of Merita Bank, the remaining Finnish commercial bank with Nordbanken of Sweden in 1997. Another restructuring occurred in 1998 between the government-owned PostOffice Bank and Vientiluotto (Export Credit Institution), which led to the creation of Leonia Bank. More recently, Merita-Nordbanken merged with a Danish bank and a Norwegian bank to form Nordea, a pan-Nordic Bank. Another merger occurred between Leonia Bank and Sampo Insurance Corporation, which created the Finnish bank-insurance conglomerate Sampo. In 2007 the banking business of Sampo was sold to the Danske Bank. As a result of all the restructurings about 60 per cent of the Finnish banking system is nowadays owned by foreigners. 


\subsection{Management of the Swedish banking crisis}

The banking crisis in Sweden erupted in the autumn 1991, starting with the largest savings bank, Första Sparbanken. The Swedish government provided a lending guarantee to the owners of the bank, though the guarantee was later converted into a loan and eventually the bank was merged into the Savings Bank of Sweden, together with several other savings banks. The second problem bank was Nordbanken, the third largest commercial bank, which was 71 per cent owned by the government already before the crisis. A share issue guaranteed by the government was made and government ownership in the bank increased. Existing shareholders were not penalized in this process. Restructuring of Nordbanken was carried out, including transfer of bad assets to a separate asset management company. In spring 1992 Gota Bank, the fourth largest commercial bank got into difficulties and was assessed not to be viable. In 1993 it was merged with Nordbanken and in this operation the shareholders of Gota Bank received nothing.

The Swedish crisis was treated in an ad hoc manner until summer 1992, but with increased turmoil the crisis was deemed systemic. Most banks, representing 90 per cent of all bank assets, incurred heavy credit losses. In the autumn 1992 the Swedish government introduced several measures to deal with the crisis. A blanket creditor guarantee was issued by the government. Riskbanken, the central bank, provided extensive liquidity support through its currency deposits in the banks and lending facilities. A crisis resolution agency (Bankstödsnämnden BSN) was set up to implement public support to the banking system. Bank support was provided in a transparent manner. It was open to all banks and the criteria were the same for different banks. The terms were strict with requirements for risk reduction, cost-cutting, and improved efficiency.

Some Swedish banks, notably Svenska Handelsbanken, S-E Banken (and two other banks), did not need public support. ${ }^{10}$ In the end 98 per cent of the public support went to two banks Nordbanken and Gota Bank (which was merged to Nordbanken in 1993). Nordbanken was eventually entered into a pan-Nordic bank Nordea, and the Swedish government still has a significant ownership (19,9 per cent in 2008) in Nordea.

\subsection{Management of the Norwegian banking crisis}

The Norwegian crisis erupted in the autumn of 1988 when a medium-sized commercial bank, Sunnmørsbanken, was hit by big loan losses. Shortly after, two savings banks also got into difficulties and in 1989-1990 further savings banks

\footnotetext{
${ }^{10}$ With the exception of Handelsbanken, the other banks initially applied for support or guarantee but did not utilize it.
} 
were also hit by capital losses. Initially, the Commercial Banks' and the Savings Banks' Guarantee Funds (CBGF and SBGF), which are private funds, provided support for the banks in difficulties and the troubled banks were later merged into other banks. Norges Bank, the Central Bank, provided liquidity loans in these cases, some part of which were not recovered in the mergers.

By late 1990 the private guarantee funds had used most of their resources and in January 1991 the government established the Government Bank Insurance Fund (GBIF) with capital of 0.6 per cent of 1991 GDP. Initially, GBIF provided additional funds for the private guarantee funds but, with continuing bank difficulties, injections of solvency support directly to problem banks became necessary. In autumn 1991 the biggest commercial banks in Norway run into deep problems and needed capital support. The 2nd and 3rd biggest banks Christiania Bank and Fokus Bank lost all of their capital, while the biggest bank, Den norske Bank, lost 90 per cent of its share capital. GBIF provided huge capital infusions to these banks under strict conditions, and by the spring 1992 all three banks were nationalized and the value of old shares was written down to zero. The government also had to take some other measures during the crisis. A blanket guarantee of the banking system was not made, though specific announcements about securing confidence in the Norwegian banking system and about securing depositors and creditors of Christiania Bank were made.

The situation of Norwegian banks started to improve rapidly in 1993. After the crisis the government had gradually sold its bank shares. Fokus Bank was placed on the market in autumn 1995 and it was later bought by Danske Bank. Christiania Bank was sold more gradually and was eventually merged with the pan-Nordic group Nordea. Similarly, shares in Den norske Bank were gradually sold. However, the government still holds 34 per cent of the bank DnB NOR, which was formed in the merger between Den norske Bank and Union Bank of Norway.

A remarkable feature of the nationalization and privatization process has been that, due to increases in share prices, the Norwegian tax payer has in the end been a net beneficiary in the crisis, ie the bank support has been more than covered from the sale of the nationalized banks. Somewhat similarly, the final net fiscal cost of the Finnish and Swedish banking turned out to be significantly smaller than the gross costs due to the re-sale of assets held by the public asset management companies. Table 2 provides one set of estimates of the costs. ${ }^{11}$

\footnotetext{
${ }^{11}$ The public costs can be calculated in different ways, depending on what is included and on the year of comparison to the size of the economy (usually GDP). Different sources give somewhat different estimates and the numbers in Table 4.1 should be viewed as indicative.
} 


\begin{tabular}{|l|l|l|}
\hline & Gross cost & Net cost (\% of 1997 GDP) \\
\hline Finland & $9.0(\%$ of 1997 GDP) & $5.3(\%$ of 1997 GDP) \\
\hline Norway & $\begin{array}{l}2.0(\% \text { of } 1997 \text { GDP) } \\
3.4 \text { (present value, } \% \text { of 2001 GDP) }\end{array}$ & $\begin{array}{l}-0.4 \text { (present value, } \% \text { of } 2001 \\
\text { GDP) }\end{array}$ \\
\hline Sweden & $3.6(\%$ of 1997 GDP) & $0.2(\%$ of 1997 GDP) \\
\hline
\end{tabular}

\section{Lessons}

Prevention of a systemic financial crisis should, in my view, be the first priority even if improved efficiency and faster economic growth can eventually occur after the crisis. ${ }^{13}$ Stability-oriented macro policies that avoid inflation and overheating are crucial in crisis prevention. The difficulty is how to diagnose an emerging overheating situation and an asset price bubble as not all business-cycle upswings, with major asset price rises, lead to a systemic financial crisis. We do not currently have a good set of indicators to diagnose the problematic situations, but a rapid expansion of credit and strongly increased leverage are likely signals for future problems. Big external deficits are another probable warning signal, at least for small open economies. Further research into the interconnections between the macro economy, financial system, and crises is most welcome.

Macroeconomic management to prevent the financial crises in the Nordic countries did not work well and thus does not provide lessons for crisis prevention. ${ }^{14}$ The weak performance points to an important lesson about the political economy aspects of financial crises. Financial liberalization was a big regime change in the Nordic economies and preventive measures were politically unpopular and could not be pushed through during boom times. It is likely that both resistance of special interest groups and lack of understanding of the changing economic environment contributed to opposition of the preventive reforms. For natural reasons this resistance disappeared during the crises and, more generally, improved willingness to reforms seems to prevail after the economies had become more open internationally.

The Nordic crises have, however, provided good cases to test the occurrence of the different channels for the impact of a financial crisis on the real economy. There is clear evidence for the role of some of the financial channels like wealth effects, but evidence about the credit crunch, ie lack of bank capital and

\footnotetext{
${ }^{12}$ See Sandal (2004), Table 3 for details.

13 Tornell and Westermann (2005) suggest that this can be the case especially in emerging economies. The subject is obviously controversial.

14 See eg Honkapohja et al (2008), Englund (1999) and Steigum (2004) for assessments, respectively, for Finland, Sweden, and Norway.
} 
quantitative finance constraints, in the Nordic crises seems to be weak. See Englund and Vihriälä (2003) and Honkapohja et al (2008) for discussions of the evidence with further references.

Crisis management by the Nordic countries has been viewed in a much more positive light. Several lessons can be drawn from the Nordic crises in this respect. $^{15}$

A key starting point is that maintaining confidence in the banking system is crucial. Finding broad bi-partisan political support for government actions ${ }^{16}$ in the crisis is important for maintaining confidence and, eg, avoidance of large-scale bank runs. Political guarantees for obligations of banks were a major step in maintaining confidence, though the Nordic countries used different approaches here. Finland and Sweden introduced formal legal guarantees, which were lifted only in 1998 and 1996, respectively. In Norway the political guarantee was less formal. A blanket guarantee can be risky as it may increase moral hazard: creditors have no reason to monitor or discipline banks. On the other hand, it must be said that the Finnish and Swedish crises were far more severe than the Norwegian one and these two crises also involved a foreign dimension.

Looking at the role of central banks, Norges Bank explicitly provided emergency liquidity support to individual banks as part of the overall support system. In effect, Riksbank of Sweden also provided liquidity support, though it was not formally of lender-of-last-resort type. In Finland the role of the central bank was different as the Bank of Finland had to handle the initial burst of the banking crisis by taking over Skopbank as an ad hoc move.

The governments in all three countries introduced crisis resolution agencies to manage the public support and the restructuring of the banking system. Establishing an agency for the crisis management that is administratively separate from the Central Bank and Financial Supervision authority is important to avoid conflicts of interest. This will also relieve a Ministry of Finance from some 'frontline' duties even if the Ministry must necessarily carry the main responsibility in crisis management. Finland and Sweden also introduced separate asset management companies to deal with the non-performing assets from the banks in trouble. Norway did not introduce such a company, but some of the banks had their own 'bad banks' to manage non-performing assets.

Crisis resolution agencies had several duties to perform. They provided capital injections to the banking system and guided the restructuring of the banking system. Liquidations were not much used (only two small banks in Norway were liquidated). Mergers and take-overs of banks were common way to achieve restructuring. A general principle was that private solutions were always tried first before a public take-over. In Finland, capital injections were made to

\footnotetext{
${ }^{15}$ See Bäckström (1997) and Ingves and Lind (1996) for a discussion of Swedish experiences and Koskenkylä (2000) and Sandal (2004) for comparisons of Nordic practices.

${ }^{16}$ Or multi-partisan support if there many major political parties in a country.
} 
private banks and public take-overs were short-lived. Government ownership was highest in Norway, where the state took over the three largest commercial banks.

The treatment of 'old' private shareholders was mixed. In Norway, existing share capital was written down to zero before the public take-over. In Finland shareholders of Skopbank took a hit but were not completely wiped out. Subsequently, support from Finnish authorities took the form of open bank assistance and existing shareholders did not lose their capital, but the terms of support included the risk of future partial state ownership. In Sweden shareholders of Gota Bank lost everything, but private owners of other banks did not. In all countries creditors were protected, except for one case in Norway.

Institutional arrangements in the public provision of bank support are naturally subject to attempts for gain by existing owners and potential future owners. These arrangements can also provide adverse incentives for different counterparties. Prompt action, openness and common yardsticks in the assessment of losses, fair asset valuations by experts, clear guidelines in restructuring, and optimal use of government funds are important to minimize moral hazard and possibilities for manipulation. It is naturally impossible to make any precise assessment of the success of policies by the Finnish, Norwegian and Swedish authorities in these respects. Nevertheless, it can be argued that crisis resolutions in these countries were not far from best practice (see eg Sandal, 2004). As emphasized eg by Allen and Gale $(1999,2007)$, the impacts of banking collapses in the three Nordic countries were short-lived and the economies recovered fairly quickly from the crisis and economic growth resumed. 


\section{References}

Allen, F - Gale, D (1999) Bubbles, Crises, and Policy. Oxford Review of Economic Policy, 15, nr 3, 9-18.

Allen, F - Gale, D (2007) Understanding Financial Crises. Oxford University Press.

Drees, B - Pazarbaşioğlu, C (1998) The Nordic Banking Crisis: Pitfalls in Financial Liberalization. IMF Occasional paper No. 161.

Edey, M - Hviding, K (1995) An Assessment of Financial Reform in OECD Countries. Economics Department Working Paper No. 154, OECD Paris.

Englund, P (1999) The Swedish Banking Crisis: Roots and Consequences. Oxford Review of Economic Policy, 15, nr 3, 80-97.

Englund, P - Vihriälä, V (2003) Financial Crises in Developed Economies: The Cases of Finland and Sweden. Pellervo Economic Research Institute Working Paper, No. 63.

Honkapohja, S - Koskela, E (1999) The Economic Crisis of the 1990s in Finland. Economic Policy, 29, 401-436.

Honkapohja, S - Koskela, E - Leibfritz, W - Uusitalo, R (2008) Economic Prosperity Recaptured: the Finnish Path from Crisis to Fast Growth. MIT Press (forthcoming).

Ingves, S - Lind, G (1996) The Management of the Bank Crisis - in Retrospect. Bank of Sweden Quarterly Review, 5-18.

Koskenkylä, H (2000) The Nordic Countries' Banking Crises and the Lessons Learned. Bank of Finland, Financial Markets Department, Working Paper $6 / 00$.

Møller, M - Nielsen, N C (1995) Some Observations on the Nordic Banking Crisis: A Survey. Working Paper 95-8, Institute of Finance, Copenhagen Business School.

Nyberg, P - Vihriälä, V (1994) The Finnish Banking Crisis and Its Handling. Bank of Finland Discussion Paper 7/94. 
Reinhard, C M - Rogoff, K S (2008) Is the 2007 US Sub-Prime Financial Crisis So Different? An International Historical Comparison. American Economic Review, 98, 339-344.

Sandal, K (2004) The Nordic Banking Crises in the Early 1990s - Resolution Methods and Fiscal Costs. In More, T G, Solheim, J A and Vale, B (Eds.): The Norwegian Banking Crisis, Norges Banks Skriftserie/Occasional Papers No. $33,77-115$.

Steigum, E (2004) Financial Deregulation with a Fixed Exchange Rate: Lessons from Norway's Boom-Bust Cycle and Banking Crisis. In More, T G, Solheim, J A and Vale, B (Eds.): The Norwegian Banking Crisis, Norges Banks Skriftserie/Occasional Papers No. 33, 23-75.

Tornell, A - Westermann, F (2005) Boom-Bust Cycles and Financial Liberalization. MIT Press.

Vihriälä, V (1997) Banks and the Finnish Credit Cycle 1986-1995. Bank of Finland Studies E:7. 


\section{BANK OF FINLAND RESEARCH DISCUSSION PAPERS}

ISSN 0785-3572, print; ISSN 1456-6184, online

1/2009 Leonardo Becchetti - Rocco Ciciretti - Iftekhar Hasan Corporate social responsibility and shareholder's value: an empirical analysis. 2009. 50 p. ISBN 978-952-462-482-4, print; ISBN 978-952-462-483-1, online.

2/2009 Alistair Milne - Geoffrey Wood The bank lending channel reconsidered. 2009. 59 p. ISBN 978-952-462-484-8, print; ISBN 978-952-462-485-5, online.

3/2009 Peter Palmroos Effects of unobserved defaults on correlation between probability of default and loss given default on mortgage loans. 2009. 28 p. ISBN 978-952-462-486-2, print; ISBN 978-952-462-487-9, online.

4/2009 Sherrill Shaffer - Iftekhar Hasan - Mingming Zhou New small firms and dimensions of economic performance. 2009. 35 p. ISBN 978-952-462-488-6, print; ISBN 978-952-462-489-3, online.

5/2009 Seppo Honkapohja The 1990's financial crises in Nordic countries. 2009. 29 p. ISBN 978-952-462-490-9, print; ISBN 978-952-462-491-6, online. 
Suomen Pankki

Bank of Finland

P.O.Box 160

준 잉

FI-00101 HELSINKI

Finland

$* .2343^{*}$ 